\title{
EFEKTIVITAS KONSUMSI JUS ALPUKAT DAN BAYAM TERHADAP PASIEN DENGAN KADAR KOLESTEROL TINGGI
}

\author{
Ari Khusuma ${ }^{1}$, Annisa Agata ${ }^{2}$ dan Arini Pradita Roselyin ${ }^{3}$ \\ ${ }^{1}$ Jurusan Analis Kesehatan, Poltekkes Kemenkes Mataram, Indonesia \\ ${ }^{2}$ Jurusan Ilmu Keperawatan, Universitas Mitra Indonesia, Lampung, Indonesia \\ ${ }^{3}$ Direktorat Registrasi Obat, Badan Pengawas Obat dan Makanan, Jakarta Pusat, Indonesia \\ ${ }^{1}$ Jl. Praburangkasari Dasan Cermen, Sandubaya Kota Mataram Telp./Fax. (0370) 633837 \\ Email : khusumaari@gmail.com ${ }^{1}$
}

\begin{tabular}{l} 
Article Info \\
\hline Article history: \\
Received July $14^{\text {th }}, 2020$ \\
Revised August $21^{\text {th }}, 2020$ \\
Accepte September $25^{\text {th }}, 2020$
\end{tabular}

\section{Keyword:}

Avocado juice and spinach; Cholesterol levels; Consuming

\begin{abstract}
Background: High cholesterol levels can cause various diseases such as atherosclerosis, coronary heart risk, heart attack, and angina. Based on a report on Rajabasa Indah Public Health Center there are 43 people with high cholesterol, one of the traditional medicine that can help lower cholesterol is avocado and spinach juice. The objective of this research was to the effect of consuming avocadoand spinach juice on blood cholesterol levels at Rajabasa Indah the Working Area of Public Health Center Lampung Province District.
\end{abstract}

Objectives : The objective of this research was to the effect of consuming avocadoand spinach juice on blood cholesterol levels at Rajabasa Indah the Working Area of Public Health Center Lampung Province District.

Methods : The type of quantitative research with experiment one group pre-test post-test design. The population was 43 people with hypertension, stroke, and heart who have high cholesterol levels in Rajabasa Indah of Public Health Center Lampung Province. 43 respondent samples were taken with accidental sampling. Data were analyzed with bivariate analysis with $T$ Dependent (paired sample) test with 95\% CI and $\alpha=0.05$.

Results : The results showed that average value 298,77 cholesterol levels before consuming spinach and avocado juice and average value 280,09 cholesterol levels after consuming juice. Bivariate analysis result with $\alpha=0.05$ showed that is an effect consuming avocado and spinach juice on to blood cholesterol levels $(p<\alpha 0,05)$. The researcher suggests to health workers to improve health education aimed at the community about risk of high cholesterol.

\begin{abstract}
ABSTRAK
Latar Belakang : Kadar kolesterol yang tinggi dapat menyebabkan berbagai penyakit seperti aterosklerosis, risiko jantung koroner, serangan jantung, dan angina. Berdasarkan laporan Puskesmas Rajabasa Indah terdapat 43 penderita kolesterol tinggi. Salah satu obat tradisional yang dapat membantu menurunkan kolesterol adalah jus alpukat dan bayam.
\end{abstract}

Tujuan : Tujuan penelitian ini adalah untuk mengetahui pengaruh konsumsi jus alpukat dan bayam terhadap kadar kolesterol darah di Wilayah Kerja Puskesmas Rajabasa Indah Provinsi Lampung.

Metode : Jenis penelitian kuantitatif dengan eksperimen one group 
pre-test post-test design. Populasi dalam penelitian ini adalah 43 penderita hipertensi, stroke, dan jantung yang memiliki kadar kolesterol tinggi di Puskesmas Rajabasa Indah Provinsi Lampung. Pengambilan sampel sebanyak 43 responden dengan accidental sampling. Data dianalisis dengan analisis bivariat dengan uji $T$ Dependent (sampel berpasangan) dengan CI 95\% dan $\alpha=0,05$.

Hasil : Hasil penelitian menunjukkan bahwa nilai rata-rata kadar kolesterol sebelum mengkonsumsi jus bayam dan alpukat 298,77 dan nilai rata-rata kadar kolesterol setelah mengkonsumsi jus 280,09. Hasil analisis bivariat dengan $\alpha=0,05$ menunjukkan ada pengaruh konsumsi alpukat dan jus bayam terhadap kadar kolesterol darah ( $p$ $<\alpha$ 0,05). Peneliti menyarankan kepada petugas kesehatan untuk meningkatkan penyuluhan kesehatan yang ditujukan kepada masyarakat tentang risiko kolesterol tinggi.

Copyright @ Jurnal Gizi Prima All rights reserved.

\section{PENDAHULUAN}

Lemak bersifat multifungsi selain seagai penyumbang energi terbanyak (30\%), lemak juga memiliki dampak yang positif dan negative terhadap kesehatan. Selain itu lemak diperlukan tubuh sebagai sumber asam lemak esensial linoleat(Hardinsyah, Riyadi, \& Napitupulu, 2012). Anjuran dari Organisasi Kesehatan Dunia (WHO) sebanyak minimal $20 \%$ dari energy total sedangkan konsumsi lemak masyakat Indonesia masih belum tercukupi dengan asumsi lemak sebagian besar berasal dari pangan nabati (Suryana \& Fitri, 2017). Angka kejadian di Indonesia sendiri menurut penelitian MONICA (Multinational Monitoring Of Trends Determinants in Cardiovaskular Disease) pada wanita sebanyak 13,4\% dan 11,4\% pria. Berdasarkan jenis kelamin dan tempat tinggal didapatkan bahwa proporsi masyarakat dengan kadar kolesterol di atas normal wanita lebih tinggi dibanding pria (Badan Penelitian dan Pengembangan Kesehatan, 2013).

Data tentang penyakit yang berhubungan dengan kolesterol yaitu jantung koroner berjumlah $22.242(0,4 \%)$ orang penderita, obesitas sebanyak 654 orang $(3,62 \%)$, yang terdiri dari pria sebanyak 215 orang (dan wanita sebanyak 439 orang $(2,43 \%)$. Penderita hipertensi sebanyak 5.906 orang $(30,17 \%)$ yang terdiri dari 2.118 $(29,05 \%)$ penderita pria dan 3788 (19,35\%) penderita pria. Penyakit stroke sebanyak 68.393 (12,3\%) (Dinkes Kota Bandar Lampung, 2014). Berdasarkan data yang diperoleh di Puskesmas Rajabasa Indah Bandar Lampung tahun 2017, kolesterol termasuk penyakit yang banyak dikeluhkan di wilayah kerja puskesmas karena dapat mempengaruhi berbagai penyakit seperti hipertensi, jantung, stroke dan obesitas. Terdapat dua cara pengobatan yang dapat dilakukan bagi penderita kolesterol tinggi seperti dengan pengobatan secara farmakologis (penurun kadar kolesterol) dan non farmakologis (pengendalikan berat badan, aktivitas fisik yang teratur, hidup sehar mengurangi asupan lemak jenuh, serta peningkatan asupan serat) (Ulfah, Sukandar, \& Afiatin, 2017) Sayuran yang dikenal dengan nama ilmiah Amaranthus spp atau yang lebih dikenal dengan nama Bayam dikenal memiliki sumber zat besi yang tinggi. Alpukat adalah buah serba guna dengan kandungan zat yang kaya akan manfaat. Penelitian sebelumnya menunjukan prevalensi kolesterol sebesar $13,13 \%$ menurun setelah konsumsi pada alpukat dengan lemak nabati yang tinggi dan tak jenuh (Wijayanti, Yulina, \& Elliya, 2014).

\section{METODE PENELITIAN}

Desain penelitian berupa desain quasi eksperimen one group posttest desain. Tidak ada rancangan kelompok perbandingan, namun dilakukan observasi pertama (pre-tes) kemudian diuji perubahan yang terjadi setelah eksperimen. Populasi penelitian adalah para penderita hipertensi, stroke dan jantung yang memiliki kadar kolesterol darah > $200 \mathrm{mg} / \mathrm{dl}$ berjumlah 43 orang di Wilayah Kerja Puskesmas Rajabasa Indah Kecamatan Rajabasa Bandar Lampung. Kriteria sampel dalam penelitian ini adalah penderita kolesterol tinggi dengan kadar kolesterol darah $>200 \mathrm{mg} / \mathrm{dl}$ dan bersedia menjadi responden. Penentuan sampel dalam penelitian ini menggunakan teknik accidental sampling. Pemberian jus alpukat dan bayam 1 (satu) kali sehari selama 2 minggu terhadap kelompok eksperimen dengan yang tidak diberikan jus alpukat dan bayam. Pengukuran kadar kolesterol darah pada saat sebelum meminum jus alpukat dan bayam, dan setelah meminum jus alpukat dan bayam 


\section{HASIL DAN PEMBAHASAN Analisis Univariat}

Tabel 1. Hasil Pengukuran Kolesterol Sebelum Mengkonsumsi Jus Alpukat dan Bayam Terhadap Kadar Kolesterol Darah

\begin{tabular}{lcccc}
\hline \multicolumn{1}{c}{ Pengukuran Kolseterol } & Mean & Min Max & n & SD \\
\hline $\begin{array}{l}\text { Pengukuran kadar kolesterol } \\
\text { sebelum mengkonsumsi jus } \\
\text { alpukat \& bayam }\end{array}$ & 298,8 & $215-435$ & 43 & 59,698 \\
\hline
\end{tabular}

Berdasarkan tabel 1 diketahui bahwa hasil pengukuran kadar kolesterol sebelum mengkonsumsi jus alpukat dan bayam didapatkan hasil rerata (mean) sebesar 298,77 dengan SD 59,698 serta nilai minimum kadar kolesterol adalah 215 dan nilai tertinggi kadar kolesterol adalah 435.

Tabel 2. Hasil Pengukuran Kolesterol Sesudah Mengkonsumsi Jus Alpukat dan Bayam terhadap Kadar Kolesterol Darah

\begin{tabular}{lcccc}
\hline \multicolumn{1}{c}{ Pengukuran Kolseterol } & Mean & Min Max & n & SD \\
\hline $\begin{array}{l}\text { Pengukuran kadar kolesterol } \\
\text { sebelum mengkonsumsi jus } \\
\text { alpukat \& bayam }\end{array}$ & 280,9 & $207-423$ & 43 & 60,710 \\
\hline
\end{tabular}

Berdasarkan tabel 2 diketahui bahwa hasil pengukuran kadar kolesterol sesudah mengkonsumsi bayam dan jus alpukat didapatkan hasil nilai rata-rata (mean) adalah 280,09 dengan standar deviasi 60,710 serta nilai minimum kadar kolesterol adalah 207 dan nilai tertinggi kadar kolesterol adalah 423.

\section{Analisis Bivariat}

Tabel 3. Analisis Pengaruh Mengkonsumsi Jus Alpukat dan Bayam terhadap Kadar Kolesterol

\begin{tabular}{lcccc}
\hline $\begin{array}{c}\text { Konsumsi Jus Alpukat dan } \\
\text { Bayam }\end{array}$ & Mean & P value & n & SD \\
\hline sebelum mengkonsumsi & 298,8 & 0,000 & 43 & 59,698 \\
Sesudah mengkonsumsi & 280,9 & & & 60,710 \\
\hline
\end{tabular}

Dari tabel 3 dapat diketahui rerata perubahan kolesterol sebelum mengkonsumsi jus alpukat dan bayam adalah 298,77 dengan standard deviasi 59,698. Pada pengukuran sesudah mengkonsumsi jus alpukat dan bayam adalah 280,09 dengan standard deviasi 60,710. Ditemukan perbedaan nilai mean antara sebelum dan sesudah mengkonsumsi jus alpukat dan bayam adalah 18,68 dengan SD 1,012, hasil uji stastistik didapatkan nilai pvalue $=0,000$. Penelitian ini membuktikan adanya perbedaan rata-rata skor nilai hasil pengukuran kadar kolesterol sebelum dan sesudah mengkonsumsi jus alpukat dan bayam.

\section{Pengukuran Kadar Kolesterol Sebelum Mengkonsumsi Jus Alpukat dan Bayam}

Hasil analisis didapatkan nilai rata-rata (mean) sebelum mengkonsumsi jus alpukat dan bayam yaitu 298,77 dengan standar deviasi 59,698 serta nilai minimum kadar kolesterol adalah 215 dan nilai tertinggi kadar kolesterol adalah 435. Dari hasil penelitian dapat dilihat bahwa hasil pengukuran kadar kolesterol responden dalam kategori tinggi dimana didapatkan nilai minimum kadar kolesterol adalah 215 dan nilai tertinggi kadar kolesterol adalah 435, untuk mencegah terjadinya komplikasi dari berbagai macam penyakit akibat kolesterol tinggi harus bisa mengubah pola hidup sehat seperti mengkonsumsi jus alpukat dan bayam.

\section{Pengukuran Kadar Kolesterol Sesudah Mengkonsumsi Jus Alpukat dan Bayam}

Hasil analisis didapatkan nilai rata-rata (mean) sesudah mengkonsumsi jus alpukat dan bayam adalah 280,09 dengan standar deviasi 60,710 serta nilai minimum kadar kolesterol adalah 207 dan nilai tertinggi kadar kolesterol adalah 423. Hal ini didukung teori yang menyatakan bahwa alpukat sumber lemak tak jenuh tunggal, jenis lemak yang membantu meningkatkan kadar kolesterol (HDL) dan menurunkan kadar kolesterol 
jahat (LDL). Alpukat mengandung betasitosterol sejenis lemak nabati yang mengurangi jumlah kolesterol yang diserap dari makanan. Pengolahan alpukat dapat dibuat dalam bentuk jus dengan mempertahankan lemak baik seperti asam oleat, lemak tak jenuh, serta serat buah yang akan meningkatkan kolesterol baik. Bayam terbukti sebagai sayuran penurun kadar kolesterol dalam tubuh. Pengolahan bayam bisa dilakukan dengan dimasak sebagai sup bayam atau segelas jus setiap hari. (Kovacs \& Mela, 2006). Dari hasil penelitian didapatkan bahwa ada perbedaan hasil pengukuran kolesterol darah setelah mengkonsumsi jus alpukat dan bayam. Dimana didapatkan nilai rentang mean antara sebelum dan sesudah mengkonsumsi jus alpukat dan bayam adalah $(18,68)$. Dengan standar deviasi sebelum mengkonsumsi jus alpukat dan bayam adalah 59,698 dan sesudah mengkonsumsi jus alpukat dan bayam adalah 60,710.

\begin{abstract}
Analisa Bivariat
Hasil penelitian didapatkan bahwa ada pengaruh yang signifikan antara pengaruh mengkonsumsi jus alpukat dan bayam terhadap kadar kolesterol darah. Dalam penelitian ini diketahui responden yang sering mengkonsumsi jus alpukat dan bayam memiliki kecenderungan mengalami penurunan kadar kolesterol lebih baik dibandingkan dengan responden yang tidak mengkonsumsi jus alpukat dan bayam. Penelitian ini didukung dengan teori yang menyatakan bahwa kolesterol adalah suatu jenis lemak yang ada dalam tubuh dengan jenisnya sepertikolesterol LDL, kolesterol HDL, total kolesterol, dan trigliserida. Di organ hati, kolesterol diangkut oleh lipoprotein untuk dibawa ke sel-sel tubuh yng memerlukan, termasuk ke sel otot jantung, otak, dan lain lain agar dapat berfungsi dengan baik(Hardinsyah et al., 2012). Beberapa faktor yang menyebabkan kolesterol meningkat ada yang tidak bisa dikendalikan yaitu genetik, jenis kelamin, usia dan etnis. Adapun faktor yang bisa dikendalikan yaitu antara pola makan, berat badan, olahraga, rokok dan penyakit tertentu.
\end{abstract}

Penatalaksanaan penderita kolesterol tinggi antara lain yaitu terapi farmakologi atau terapi dengan cara minum obat kolesterol seperti bile acid sequestrants, statin, niacin dan lain-lain, dan terapi nonfarmakologi yaitu terapi tanpa obat tetapi dengan mengkonsumsi makanan yang bisa menurunkan kadar kolesterol seperti ikan omega 3, biji bunga matahari, gandum, mangga, alpukat dan bayam. (Noventi, Rusdianingseh, \& Khafid, 2019)

Hasil pengukuran kadar kolesterol sebelum mengkonsumsi jus alpukat dan bayam didapatkan nilai mean 298,77 jika dikaji lebih lanjut hasil tersebut menunjukkan bahwa pasien dengan kadar kolesterol tinggi belum mengetahui cara membantu menurunkan kolesterol selain dengan minum obat. Hal tersebut yang membuat pasien tidak mencoba mengkonsumsi buah atau sayuran yang dapat membantu menurunkan kadar kolesterol selain dengan minum obat dan belum mengetahui bagaimana cara membuat obat tradisional yang dapat membantu menurunkan kolesterol, tetapi ada juga klien yang kurang teratur dalam mengkonsumsi just alpukat dan bayam sehingga kadar kolestero masih tetap tinggi. Hasil pengukuran kadar kolesterol setelah mengkonsumsi jus alpukat dan bayam didapatkan nilai mean 280,09 hal tersebut menunjukkan bahwa ada penurunan dari hasil pengukuran kadar kolesterol sebelum mengkonsumsi jus alpukat dan bayam dan sesudah mengkonsumsi jus alpukat dan bayam dengan rentang nilai 18,68. Hasil pengukuran kolesterol tersebut menunjukkan bahwa dengan adanya pemberian terapi pedamping obat yaitu jus alpukat dan bayam berpengaruh terhadap penurunan kadar kolesterol.

Jus alpukat dan bayam adalah salah satu obat tradisional yang efektif untuk membantu menurunkan kadar kolesterol pada pasien yang menderita kadar kolesterol tinggi. Rentang nilai hasil pengukuran sebelum dan sesudah mengkonsumsi jus alpukat bayam adalah 18,64 ini menunjukkan bahwa terdapat penurunan kadar kolesterol walaupun penurunan hanya sedikit, hal ini mungkin karena responden tidak mengkonsumsi jus alpukat dan bayam sesuai yang dianjurkan oleh petugas kesehatan yaitu 1 kali dalam sehari selama 1 minggu, ada kemungkinan responden tidak minum jus alpukat dan bayam setiap hari melainkan hanya sesekali saja, sehingga hasil penurunan kolesterol hanya sedikit, disamping itu pasien juga dalam keadaan tidak minum obat penurun kadar kolesterol. Penelian ini didukung oleh penelitian yang dilakukan oleh Wijayanti, Yulina, Rahma Elliya tahun 2014 dengan judul pengaruh pemberian jus alpukat terhadap penurunan kolesterol tikus putih jantan di kota Bandar Lampung didaptkan hasil prevalensi kolesterol sebesar 13,13\%. Hal ini menunjukkan kandungan alpukat lemak nabati yang tinggi dan tak jenuh bermanfaat untuk menurunkan kolesterol LDL sehingga dapat berguna untuk mencegah stroke, penyakit jantung, darah tinggi dan kanker (Wijayanti et al., 2014). Hasil penelitian membuktikan bahwa mengkonsumsi just alpukat dan bayam yang 
diberikan secara teratur terbukti berhasil menurunkan kadar kolesterol jahat (LDL) sehingga pasien akan dapat merasakan manfaat jus alpukat dan bayam untuk kesehatan.

\section{KESIMPULAN}

Pada penelitian didapatkan nilai hasil pengukuran kolesterol sebelum mengkonsumsi jus alpukat dan bayam dengan nilai rata-rata 298,77 dan standar deviasi 59,698 dan setelah mengkonsumsi jus alpukat dan bayam dengan nilai rata-rata 280,09 dan standar deviasi 60,710. Hasil pengujian terhadap variabel yang diteliti didapat hasil signifikan sehingga konsumsi alpukat dan bayam dapat menjadi alternatif dalam upaya penurunkan kadar kolesterol darah

\section{SARAN}

Jus alpukat dan bayam merupakan salah satu terapi non farmakologi yang cukup efektif. Dengan begitu diharapkan pasien dapat melanjutkan secara rutin sebagai terapi pedamping obat dalam upaya membantu menurunkan kadar kolesterol setiap pasien dengan kadar kolesterol tinggi.

\section{DAFTAR PUSTAKA}

Badan Penelitian dan Pengembangan Kesehatan. (2013). Riset Kesehatan Dasar 2013. Riset Kesehatan Dasar 2013.

Dinkes Kota Bandar Lampung. (2014). Profil Kesehatan Kota Bandar Lampung Tahun 2014. Dinas Kesehatan Kota Bandar Lampung.

Hardinsyah, Riyadi, H., \& Napitupulu, V. (2012). Kecukupan energi, protein, lemak dan karbohidrat. Departemen Gizi FK UI.

Kovacs, E. M. R., \& Mela, D. J. (2006). Metabolically active functional food ingredients for weight control. Obesity Reviews. https://doi.org/10.1111/j.1467-789X.2006.00203.x

Noventi, I., Rusdianingseh, R., \& Khafid, M. (2019). Prevalensi, Karakteristik dan Faktor Resiko Prediabetes di Wilayah Pesisir, Pegunungan dan Perkotaan. Jurnal Ners Dan Kebidanan (Journal of Ners and Midwifery). https://doi.org/10.26699/jnk.v6i3.art.p371-381

Suryana, S., \& Fitri, Y. (2017). Hubungan Aktivitas Fisik dengan IMT dan Komposisi Lemak Tubuh. AcTion: Aceh Nutrition Journal. https://doi.org/10.30867/action.v2i2.64

Tri, H. (2011). Kajian tentang potensi bahan-bahan Alami untuk menurunkan kadar kolesterol darah. Prosiding Seminar Nasional Penellitian, Pendidikan Dan Penerapan MIPA.

Ulfah, M., Sukandar, H., \& Afiatin, A. (2017). Hubungan Kadar Kolesterol Total dengan Tekanan Darah pada Masyarakat Jatinangor. Jurnal Sistem Kesehatan. https://doi.org/10.24198/jsk.v3i2.15004

Wijayanti, Yulina, \& Elliya, R. (2014). Pengaruh Pemberian Jus Alpukat ( Persea Americana Mill ) Terhadap Penurunan Kolestrol Tikus Putih Jantan ( Rattus Novergicus ) Galur Wistar Kota Bandar Lampung Tahun 2014. Jurnal Kesehatan, 8(3), 147-152. 